\title{
TENAGA PRANA SEBAGAI TERAPI ALTERNATIF BAGI PENYEMBUHAN PENYAKIT PASIEN (STUDI TERHADAP METODE PENYEMBUHAN ALTERNATIF DI KLINIK PENGOBATAN YAYASAN MAJLIS TAKLIM AL- UKHUWAH BUAH BATU BANDUNG)
}

\author{
Dian Siti Nurjanah \\ UIN Sunan Gunung Djati Bandung
}

\begin{abstract}
ABSTRAK
Salah satu teknik pengobatan penyakit pasien adalah dengan menggunakan tenaga prana, tenaga prana atau energi chi adalah teknik penyembuhan yang didasarkan atas struktur keseluruhan tubuh manusia yang terdiri dari tubuh fisik dan tubuh energi yang tidak tampak yang disebut tubuh bioplasmik.Prana disamping untuk terapi penyembuhan fisik, bagi sebagian orang juga sebagai upaya mencari keseimbangan secara psikis. Targetnya jangka panjang mencari jalan supaya bisa hidup tenang di tengah-tengah suasana masyarakat yang sedang bergolak. Dan bagi mereka yang sedang dilanda putus asa bukan tidak mungkin metode pengobatan yang mengandalkan energi alam ini sebagai alternatif healing.
\end{abstract}

\section{KATA KUNCI}

Prana; Aura; Chakra; Bioplasmik; Tubuh eterik; Scanning; Spektrum; Allophatic; Yoga; Psikoterapi

DOI: https://doi.org/10.15575/saq.v1i2.1432

\section{A. PENDAHULUAN}

Kemajuan teknologi juga diikuti dengan kemajuan medis dan kedokteran, dengan munculnya produk-produk baru peralatan medis dari obat-obatan, suntikan, transfusi yang adakalanya mengakibatkan efek samping dari zat kimiawi yang di konsumsi bagi pasien penderita, hal ini bisa mengakibatkan terganggunya organ tubuh yang lain, apalagi dikonsumsi secara terus menerus, Zat tersebut akan mengendap dalam tubuh sehingga muncul penyakit seperti ginjal, kanker, jantung dan sebagainya. Disamping juga karena mengkonsumsi makanan yang tidak sehat karena tidak mengandung unsur empat sehat lima sempurna atau kemasan makanan yang di tambah dengan zat kimia lain untuk mengawetkan, sebagai penyedap, pewarna yang sangat berbahaya bagi kesehatan tubuh. Di Era informasi dan teknologi yang serba canggih orang terkadang ingin memperoleh makanan yang serba cepat dan instant karena kesibukan, dan makanan "fast food", makanan kalengan, snack, ini menjadi sangat digemari, walaupun terkadang tidak memperhitungkan efek negatifnya, sampai akhirnya mengalami gangguan atau sakit. Tetapi ada orang yang akhirnya sadar akan menjaga kesehatan dan meminimalisir mengkonsumsi makanan yang tidak alami dengan mengganti dengan sayuran dan buah-buahan segar agar mengurangi resiko penyakit seperti kanker, tumor, kolesterol, maag dan lain-lain.

Dalam proses penyembuhanpun saat ini dengan kemajuan teknologi kedokteran dan telah banyak tawaran obat-obatan yang ditawarkan, dari obat batuk saja ada berbagai macam jenis seperti, komik, kalibek, laserin, vick, benadril, mextril dan masih banyak lagi. Sehingga konsumen menjadi bingung dan 
menjadi kelinci percobaan. Karena hal ini ada sebagian orang yang merasa jenuh dengan pengobatan secara kedokteran dengan mencoba macam-macam obat kimiawi, suntikan, operasi dan cara medis lainnya, sehingga kemudian pasien atau klien yang menderita sakit itu mencari alternatif lain sebagai upaya penyembuhan, yang itu akan meminimalisir efek samping dari zat kimia yang membahayakan dan kembali ke proses penyembuhan dengan kembali ke alam atau pengobatan tradisional. Banyak alternatif yang dapat dipilih penyembuhan yang dapat dipilih penyembuhan secara tradisional ini, bisa dengan pijat refleksi, akupuntur, dengan sengatan lebah, menjaga kebugaran dengan Yoga, cara sehat ala Dr. Hembing, atau dengan terapi dzikir, terapi do'a seperti kata Larry Dossey M.D. (1997) mengungkapkan "Studi terhadap sekelompok orang memperlihatkan bahwa do'a secara positif mempengaruhi tekanan darah tinggi, luka, serangan jantung, sakit kepala, dan kecemasan".

Juga ada terapi alternatif yang lain yang digunakan sebenarnya sudah ribuan tahun yang lalu digunakan dalam tradisi Cina, Jepang dan India dengan seorang tabib, Prana akhir-akhir ini menjadi sangat diminati bagi pasien yang ingin sembuh.

Prana adalah daya hidup yang mampu memberdayakan apapun di dunia ini, pada dasarnya prana merupakan energi dari daya hidup itu sendiri, yang bertanggung jawab dalam seluruh gerakan dalam dunia sadar, semua sistem pengobatan bekerja dalam beberapa aspek prana. meskipun mereka tidak mengerti apakah prana itu. meski pengobatan Allopathic tidak mengakui prana sebagai suatu kesatuan di dalamnya, prana tetap mempengaruhi daya hidup kita dalam berbagai cara. Pengobatan Allopathic menjelaskan berbagai sirkulasi atau homeostatis. Oleh karena itu seseorang dapat mengatakan bahwa penyembuhan adalah cara prana. (David Framley, 2001:2).

Penyembuhan cara prana juga berhubungan dengan sistem Yoga, Yoga tidak hanya sebentuk sistem latihan atau meditasi, ia merupakan bentuk kerja yang tak kentara antara energi tubuh dan pikiran dan yang merupakan unsur terpenting dari Prana.

Pengobatan alamiah menggunakan berbagai bahan sebagai alat untuk prana, seperti makan, ramuan-ramuan semua ini sangat mempengaruhi dan menunjang bekerjanya prana secara optimal sebagai langkah menuju terapi pemanasan dan pendinginan, atau meningkatkan kualitas dan unsur yang terkait di dalamnya.

Beberapa sistem pengobatan tradisional juga menggunakan cara kerja prana seperti Akupuntur, pemijat tubuh, dalam hal ini mereka mengobati dengan Prana langsung. Sentuhan dalam bentuk apapun yang mengalirkan Prana, karena sentuhan adalah kualitas sensoris yang menghubungkan dengan elemen, tempat Prana. atau pernafasan.

Penggunaan prana secara langsung untuk tujuan penyembuhan bersamaan dengan alat lain untuk prana. seperti makanan atau ramuan atau olah diri sendiri kita dapat belajar memproyeksikan kekuatan tenaga prana secara langsung untuk penyembuhan kita sendiri atau orang lain misalnya dengan latihan Pranama (Latihan Pernafasan) kita dapat mengarahkan energi pernafasan secara langsung menggunakan tenaga pikiran terutama dengan melalui visualisasi. Dimanapun kita menempatkan perhatian kita, kita juga menempatkan beberapa aspek dari prana atau tenaga kita. Semakin kuat konsentrasi kita, semakin besar kekuatan prana yang dapat kita hasilkan.

Pemijatan tubuh dapat mengatur pernafasan mereka, bersamaan dengan mengobati pasien. Ini memastikan sebuah aliran energi penyembuhan yang lebih positif. Ahli akupuntur dan tusuk jari mengetahui pentingnya menempatkan chi mereka dalam titik-titik akupuntur.

Sedangkan Choa Kok Sui menyebutkan bahwa penyembuhan pranik atau penyembuhan dengan prana merupakan pengetahuan dan seni penyembuhan kuno yang menggerakkan prana atau ki atau energi vital untuk penyembuhan tubuh fisik "Penyembuhan dengan prana juga mengakibatkan manipulasi ki dan bahan 
bioplasmik tubuh penderita. Cara seperti ini sering pula dikatakan penyembuhan psikis, penyembuhan magnetik, penyembuhan kepercayaan, penyembuhan ki, vitalik, peletakan tangan, sentuhan terapetik dan penyembuhan kharismatik". (Choi Kok Sui, 2000:3).

Haji Nana Sumarna (Ketua Majlis Taklim Al-Ukhuwah) mengklasifikasikan cara pengobatan dengan dua macam: yaitu pendekatan kedokteran barat dengan didasarkan pada bahan atau zat kimia dalam penyembuhan pasien, dan pendekatan kedokteran timur khususnya Cina dan India pendekatan ini didasarkan pada keserasian prana di dalam tubuh manusia sebagai energi dinamis dalam aliran tetap yang beredar melalui seluruh tubuh. (Kompas, 1997:13).

Pada tahap evolusi sekarang, manusia sedikit menyadari tenaga prana dan akibatnya sangat mengidentifikasi dirinya dengan bahan, menipu dirinya bahwa ia merupakan tubuh itu. Seorang pakar terkenal dalam Yoga dan kedokteran Dr. Steven Brena, menulis dalam bukunya bahwa :

"Manusia juga lupa bahwa itu bukanlah apaapa melainkan energi padat yang merubah secara sinambung. Ia merubah energi vital untuk mengisi indranya dengan berbagai rangsangan, maka lahirlah dari sebuah rantai keinginan materi yang tidak ada hentinya. semakin ia memikirkan hal itu, semakin dibutuhkan makanan berdaging untuk bertahan hidup dan ia semakin membakar habis oksigen maka sedikit ia merasakan tenaga prana yang ada dalam dirinya. Situasi ini membuatnya terbenam dalam bahan dan dengan prana yang berkurang ia mengalami penipisan" (Steven Brena: 125).

Para pewaskita dengan menggunakan kemampuan psikis telah mengamati bahwa: setiap orang di kelilingi dan dirasuki tubuh energi bercahaya yang disebut tubuh bioplasmik. Kata bioplasmik berasal dari Bio yang berarti hidup dan Plasma berarti keadaan bahan ke empat setelah bahan padat, cair dan gas. (Chua Kok Sui, 2000:3). Plasma yang dimaksudkan tidak sama dengan plasma darah, tubuh bio plasmik berarti tubuh energi yang hidup yang terbentuk dari bahan halus yang tidak tampak atau bahan eterik. Melalui tubuh bioplasmik prana atau energi vital, diserap dan di distribusikan ke seluruh tubuh fisik.

Tubuh bioplasmik memiliki chakra atau pusat energi yang berputar dalam titik-titik pusat tubuh dan sangat penting sebagaimana tubuh fisik memiliki organ vital. Tubuh bioplasmik memiliki chakra mayor, minor dan mini. Chakra mayor mengendalikan dan memberikan energi vital pada tubuh fisik, chakra minor dan mini mengendalikan dan memberi energi kepada tubuh fisik yang kurang penting. Chakra tersebut merasuk ke dalam dan meluas keluar tubuh fisik.

Tubuh bioplasmik melalui sinar kesehatan atau aura kesehatan bertindak sebagai bahan pelindung dari penyakit. Aura kesehatan mengelilingi manusia yang merupakan medan energi pada tubuh jasmani. Aura akan memancar tiga hingga empat meter di sekeliling tubuh manusia dan memiliki warna aura hal ini dapat dilihat oleh pewaskita (yang sudah peka) dan sekarang dengan ilmu pengetahuan modern memiliki kemampuan membuktikannya dengan menggunakan Fotografi Kirlian. Para ilmuan telah mampu mengamati dan mengambil gambar tubuh bioplasmik dan aura yang mengelilinginya.

Tempi prana yang dilakukan melalui teknikteknik yaitu scanning atau pendeteksian penyakit di bagian mana keluhan penyakit dirasakan setelah itu dilakukan penyapuan baik secara lokal dan menyeluruh kemudian setelah bersih pemberian energi ke dalam tubuh yang sakit pada tubuh bioplasmik, terakhir pemutusan energi antara terapis dengan pasien, hal ini dilakukan dengan tangan yang sudah peka. 


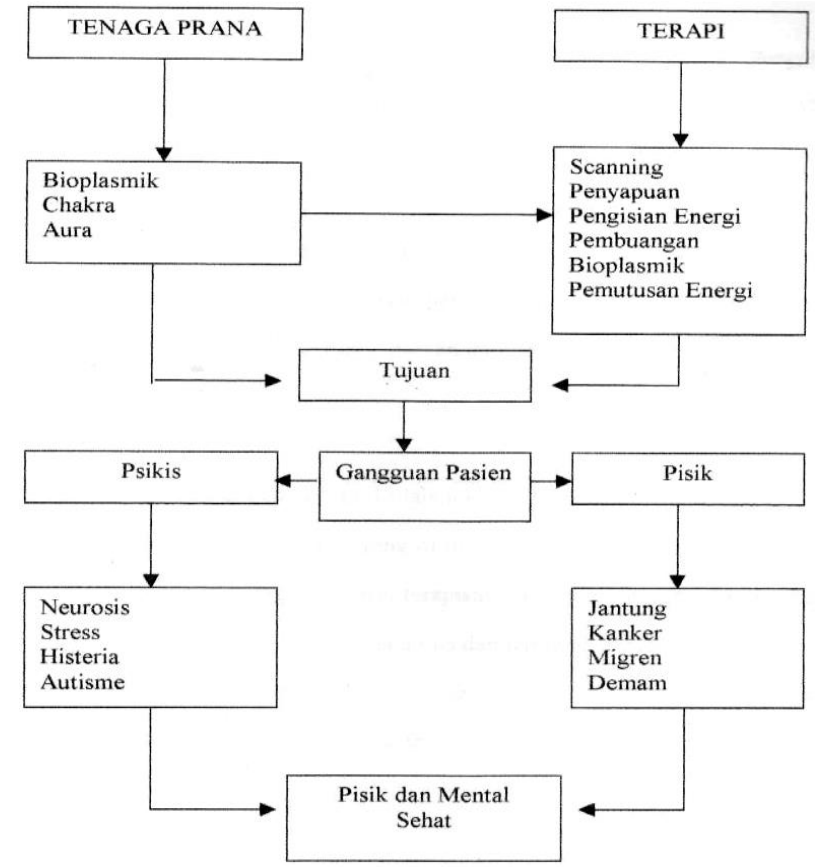

Skema Tenaga Prana Sebagai Terapi

\section{B. TENAGA PRANA DAN PSIKOTERAPI 1. Pengertian Prana}

Prana berasal dari istilah sansekerta yang berarti energi vital atau tenaga hidup yang mempertahankan kehidupan dan kesehatan tubuh. Choa Kok Sui (1998:2). Istilah prana sendiri populer di India, dalam bahasa Yunani dikenal dengan istilah pneuma, dalam bahasa polinesia disebut mana, sedangkan dalam bahasa Yahudi disebut ruah, yang berarti nafas kehidupan, di Cina disebut chi, di Jepang disebut energi $K i$, dan di Barat sendiri dengan istilah odic force, $x$ force, orgone force dan etheric force

Pada dasarnya terdapat beberapa sumber utama prana, yaitu:

a. Prana matahari

Prana matahari berasal dari sinar matahari untuk memperkuat tubuh dan membentuk tubuh menjadi sehat. Titik masuk tenaga matahari ini adalah chakra mahkota dan titik akhirnya adalah chakra dasar.

b. Prana udara

Prana udara disebut juga dengan butir-butir vitalitas udara, prana udara diterap oleh paru-paru melalui proses pernafasan dan juga doserap secara langsung oleh pusat energi tubuh bioplastik. Prana udara lebih banyak diserap dengan pernafasaan berirama yang lembut dan dalam, dari pada pernafasan yang dangkal dan pendek. Prana udara juga bisa diserap melalui pori-pori kulit orang yang telah menjalani latihan tertentu (pernafasan pori-pori). Titik masuk tenaga prana udara adalah limpa dan paruparu.

c. Prana bumi

Prana bumi atau butir-butir vitalitas bumi yang dapat menghembus bumi dan terlentang beberapa inci di atasnya. Prana bumi ini lebih padat lebih besar dibandingkan dengan prana udara, karena prana bumi ini bisa menyerap secara otomatis dengan telapak kaki. Berjalan dengan kaki tidak beralas meningkatkan jumlah prana bumi yang diserap tubuh. Orang dapat belajar untuk secara sadar menyerap lebih banyak menyerap prana bumi untuk meningkatkan vitalitasnya, kapasitas untuk lebih bekerja lebih banyak dan kemampuan untuk berfikir secara lebih jernih. Sebagian prana bumi diarahkan ke tulang punggung dan chakra lainnya, misalnya pada chakra minor yang terdapat di selangkang, ke chakra pusar dan chakra limpa. Titik masuk tenaga prana bumi adalah chakra dasar dan chakra minor telapak kaki.

d. Prana pohon

Prana pohon ini terdapat dibeberapa jenis pohon seperti: pohon pinus atau pohon raksasa yang sehat dan tua, prana pohon ini telah memancarkan sebagian besar kelebihan prananya. Orang yang lelah atau sakit mendapat banyak manfaat dengan berbaring atau beristirahat di bawah pohon tersebut.

e. Prana makanan

Prana makanan banyak diperoleh dari buah-buahan segar dan sayuran.

f. Prana air

Prana air menyerap dari prana matahari, bumi dan udara dimana air itu mengalir seperti mata air, sungai dan muara.

\section{Manfaat Penyembuhan dengan Prana}

Prana dapat juga digunakan untuk mengobati orang lain dan juga banyak digunakan oleh para ahli akupuntur, 
akupreasure serta refleksiologi. Akupuntur merupakan bentuk pengobatan di Cina kuno yang menggunakan jarum untuk manipulasi energi vital dalam tubuh penderita dan dengan demikian penyembuhan penyakit ini dicapai dengan menggunakan jarum untuk mendistribusikan ulang prana atau $K i$ yang berlebihan dalam tubuh penderita sebab sebagian yang terganggu. Tersekatnya energi atau kongesti prana dibagian yang sakit didistribusikan kebagian tubuh yang lain. Meridian atau saluran bioplasmik yang tersumbat dibersihkan atau dibuka dengan mengarahkan $K i$ ke meridia tersebut.

Akupreasur atau refleksiolagi prinsipnya sama dengan akupuntur kecuali bahwa secara sadar atau tidak menggunakan kelebihan prananya sendiri. Kelebihan prananya sendiri ini diarahkan ketitik akupreasure yang kemudian menuju meridian atau saluran bioplasma, lalu kebagian yang terganggu. Beberapa ahli akupuntur menggunakannya dan mengarahkan energi vital atau $K i$ mereka kedalam jarum dalam usaha mencapai bagian yang sakit. Hal ini terutama dilakukan pada penderita yang lemah atau kehabisan prana. Menurut Choa Kok Sui (1998:4) ada beberapa manfaat dalam penyembuhan dengan menggunakan tenaga prana yaitu:

1. Penyembuhan dengan tenaga prana dapat membantu para orang tua menurunkan suhu anak mereka yang menderita demam yaitu yang tinggi, dalam beberapa jam saja dan pada sebagian besar kasus dapat menyembuhkannya dalam satu hari atau dua hari.

2. Penyembuhan dengan prana juga dapat menghilangkan sakit kepala, sakit kembung, sakit otot pada sebagian kasus.

3. Penyembuhan dengan prana juga dapat menghilangkan sakit batuk dan selesma dalam satu atau dua hari. Diare dapat disembuhkan dalam beberapa jam pada sebagian kasus.

4. Penyakit berat seperti sakit mata, hati, ginjal, dan gangguan jantung, dapat diringankan dengan beberapa perawatan, dan disembuhkan dalam beberapa bulan pada sebagian kasus.
5. Penyembuhan dengan prana dapat meningkatkan laju penyembuhan tiga kali lebih cepat ketimbang laju normal penyembuhan.

\section{Tubuh Bioplasmik (tubuh energi)}

Kata bioplasmik berasal dari "bio" yang berarti hidup dan "plasma" yang berarti keadaan bahan keempat. Plasma yang dimaksudkan disini tidak sama dengan plasma darah. Tubuh bioplasmik berarti tubuh energi yang hidup yang terbentuk dari bahan yang halus yang tidak tampak atau bahan eterik. Setelah ketiga bahan yang pertama yaitu: padat, cair, dan gas. Plasma yang teronisasi atau gas yang mengandung partikel positif dan negatif. Choa Kok Sui (2000:3).

\section{Hubungan tubuh bioplasmik dengan tubuh fisik}

Tubuh eterik atau tubuh bioplasmik sebenarnya masih merupakan bagian dari tubuh fisik dan sangat penting artinya bagi kehidupan badan. Ia juga merupakan jembatan penghubung guna menyalurkan gelombang pikiran dan perasaan dari badan astral yang halus ke badan fisik yang padat. Tubuh eterik juga berfungsi untuk menyerap dan mendistribusikan energi vital ke seluruh tubuh fisik.

Tubuh eterik merupakan tubuh energi bercahaya, tidak tampak, tidak dapat diraba, merasuk ke dalam tubuh fisik dan menembus keluar dengan ketebalan beberapa centimeter. Karena sifatnya yang demikian, tidaklah mengherankan apabila bentuk tubuh eterik mengikuti bentuk tubuh fisik sehingga seringkali disebut dengan pola tubuh fisik.

Walaupun terdiri dari bahan yang halus, tubuh ini masih dapat dilihat dengan mata biasa, yaitu dengan cara memperhatikan tubuh objek secara cermat, sampai terlihat adanya sinar putih berwarna perak mengelilingi tubuh. Yang dilihat memang tidak terlalu jelas tetapi cukup untuk menunjukkan keadaan tubuh itu. Bagi orang yang peka atau waskita tubuh ini tampak seperti kabut berwarna ungu, abu-abu dan sebagainya agak berkilauan. Keberadaan tubuh ini telah dapat dibuktikan oleh ilmu 
pengetahuan yaitu dengan ditemukannya fotogrqfi Kirlian. R.Soegoro. S E,MA (2001 :46).

\section{Chakra atau Pusat Energi}

Menurut Irmansyah Efendi, Msc (2001:76) menyebutkan bahwa chakra berasal dari bahasa sansekerta yang berarti roda, karena apabila dilihat dari depan terlihat seperti sebuah roda yang berputar, gambaran sebuah roda ini sendiri karena chakra sebenarnya terdiri dari beberapa lembaran daun yang bervariasi jumlahnya pada setiap chakra. Dibelakang chakra terdapat pula sebuah roda lainnya yang lebih kecil yang berfungsi sebagai pelindung.

Sedangkan R. Soegoro SE, MA (2001:46) seorang master reiki menyebutkan bahwa chakra itu selain disebut roda atau lingkaran juga sebagai "simpul energi" atau pusat daya yang terlihat seperti cekungan yang mirip dengan pusaran air atau sebuah piring yang menempel di tubuh eterik,

Choa Kok Sui (2000: 11) membagi kedalam tiga macam chakra yaitu: chakra mayor, chakra minor dan chakra mini. Chakra mayor merupakan pusat energi berputar yang bergaris tengah sekitar tiga sampai empat inci. Chakra mayor mengendalikan dan memberikan energi kedalam organ vital dan organ mayor pada tubuh fisik. Chakra mayor bekerja sebagai pembangkit tenaga listrik yang menyatu energi vital kedalam organ mayor dan vital. Bila pembangkit tenaga ini tidak berfungsi, organ vital menjadi sakit atau berpenyakit karena mereka tidak mempunyai cukup energi vital untuk bekerja secara benar. Chakra minor bergaris tengah sekitar satu sampai dua inci. Chakra mini bergaris tengah kurang dari satu inci. Chakra minor dan mini mengendalikan dan memberikan energi kepada bagian tubuh fisik yang kurang penting. Chakra tersebut merasuk kedalam dan meluas keluar tubuh fisik. Chakra minor ini terdapat pada bagian tangan dan kaki sedangkan chakra mini terdapat di bagian ujung-ujung kaki.

\section{Sebelas Chakra Mayor}

Choa Kok Sui (2000:12) membagi chakra mayor kedalam sebelas bagian, yaitu:

\section{a. Chakra dasar}

Chakra ini terletak di dasar tulang punggung. Chakra dasar mengendalikan, memberikan energi dan memperkuat seluruh tubuh fisik yang tampak ia mengendalikan dan memberikan energi kepada otot dan sistem rangka, tulang punggung, produksi dan sifat darah yang dihasilkan, kelenjar adrenal, jaringan tubuh dan organ dalam. Ia juga mempengaruhi dan memberikan energi ke dalam organ seks. Chakra ini mempengaruhi panas tubuh vitalitas uraum dan pertumbuhan bayi dan anak kecil. Gangguan chakra ini akan bermanifestasi sebagai radang sendi atau artritis, gangguan tulang punggung, gangguan darah, kanker, kanker tulang, leukimia, alergi, gangguan pertumbuhan, vitalitas rendah, dan lambatnya pertumbuhan dan vitalitas rendah, lambatnya penyembuhan luka dan patah tulang.

\section{b. Chakra seks}

Chakra ini terletak di daerah kemaluan. Tugasnya mengendalikan dan memberikan energi kedalam organ seks dan organ kandung kencing. Gangguan fungsi seks akan bermanifestasi sebagai penyakit yang berhubungan dengan seks. Chakra ajna, chakra tenggorokan dan chakra dasar berpengaruh kuat pada chakra seks. Gangguan fungsi salah satu chakra tersebut akan menyebabkan gangguan fungsi chakra seks.

\section{c. Chakra meng mein}

Chakra ini terletak di belakang pusar. Ia berfungsi sebagai gardu pompa di dalam tulang punggung yang bertanggung jawab untuk aliran energi prana yang halus yang berasal dari chakra dasar ke atas. Ia mengendalikan dan memberi energi kepada ginjal dan kelenjar adrenal. Ia juga mengatur tekanan darah. Gangguan fungsi chakra meng mein akan bermanifestasi sebagai penyakit ginjal, vitalitas rendah, tekanan darah tinggi dan penyakit punggung. 


\section{d. Chakra pusar}

Chakra ini terletak di pusar, tugasnya mengendalikan dan memberikan energi kepada usus kecil, usus besar, usus buntu. Chakra ini mempengaruhi vitalitas umum seseorang. Gangguan fungsi chakra pusar akan bermanifestasi sebagai sembelit, radang usus buntu, kesulitan melahirkan, vitalitas rendah, dan penyakit lain yang berhubungan dengan usus.

\section{e. Chakra limpa}

Chakra limpa depan terletak di bagian kiri perut antara chakra solar-plexus dan chakra pusar. Tempetnya di bagian tengah rusuk daras kiri. Chakra limpa merupakan tempat masuk utama untuk prana udara atau butir-butir vitalitas udara, karena itu chakra ini memegang peranan penting dalam kesehatan tubuh seseorang. Tugasnya memberikan energi kepada chakra mayor lain dan seluruh tubuh dan mendistribusikan prana yang sudah dicernakan kepada chakra-chakra mayor dan seluruh tubuh. Chakra limpa belakang terdapat dibagian belakang chakra limpa depan mempunyai fungsi yang serupa.

\section{f. Chakra solar plexus}

Ada dua chakra solar plexus yang terletak di daerah solar plexus atau daerah cekung diantara rusuk, disebut chakra solar plexus depan dan yang terletak di bagian belakang yang disebut chakra solar plexus belakang. Istilah "Chakra Solar plexus" berarti kedua chakra yaitu depan dan belakang. Chakra ini juga mempengaruhi kualitas darah karena ia mengendalikan dan memberikan energi kepada hati yang menghilangkan racun dari darah. Chakra solar plexus merupakan pusat pemprosesan energi. Energi halus dari chakra yang lebih rendah dan lebih tinggi mengalir melaluinya. Seluruh tubuh dapat diberi energi melalui chakra solar plexus. Pada beberapa kejadian yang jarang, pemberian energi secara berlebihan pada chakra ini tanpa didahului dengan penyapuan energi dengan seksama, dapat menyebabkan kongesti prana, dengan demikian melumpuhkan sebagian diafragma, yang akan menyebabkan kesulitan pernafasan. kongesti prana harus segera dihilangkan. Chakra solar plexus juga mengendalikan sistem pernafasan dan pendinginan tubuh. Gangguan fungsi chakra ini akan bermanifestasi sebagai diabetes, tukak lambung, radang hati, penyakit jantung dan penyakit lainnya yang berkaitan dengan organ tersebut.

\section{g. Chakra jantung}

Chakra jantung depan terletak dibagian tengah dada. Tugasnya mengendalikan dan memberikan energi kepada jantung, kelenjar timus dan sistem peredaran darah. Gangguan fungsi chakra jantung depan akan bermanifestasi sebagai penyakit jantung dan peredaran darah. Chakra solar plexus sangat peka terhadap emosi, ketegangan dan stres, serta mempunyai pengaruh kuat pada jantung fisik dan chakra jantung depan. Gangguan chakra solar plexus dapat menyebabkan chakra jantung depan dan jantung fisik juga terganggu fungsinya. Chakra jantung berhubungan erat dengan chakra solar plexus depan melalui beberapa saluran bioplasmik yang besar, dan sampai batas tertentu juga diberi energi oleh chakra solar plexus depan. Pasien dengan penyakit jantung biasanya mengalami gangguan fungsi chakra solar plexus depan. Chakra jantung belakang terletak dibagian belakang jantung. Ia terutama mengendalikan dan memberikan energi kepada paru-paru dan pada tingkat jantung belakang akan bermanifestasi sebagai penyakit paruparu, seperti asma, tubercolosis, dan Iain-lain.

\section{h. Chakra tenggorokan}

Chakra ini terdapat dibagian tengah tenggorok. Tugasnya memberikan energi ke tenggorok, kelenjar tiroid, kelenjar paratiroid, dan sistem getah bening. Sampai batas tertentu chakra tenggorok juga mempengaruhi chakra seks. Kurang berfungsinya chakra tenggorok bermanifesiasi sebagai penyakit yang berkaitan dengan tenggorok misalnya, gondok, sakit tenggorok. ilangnya suara, asma dan sebagainya. 


\section{Chakra ajna}

Chakra ini terletak diantara kedua alis mata. Tugasnya mengendalikan dan memberikan energi kepada kelenjar hiposis, kelenjar endokrin dan sampai batas tertentu memberikan energi kepada otak. Ia juga disebut chakra master/induk karena ia mengatur dan mengendalikan chakra mayor lain serta kelenjar endokrin dan organ vital terkait. Ia juga mempengaruhi mata dan hidung. gangguan fungsi chakra ini bermanifestasi sebagai penyakit yang berkaitan dengan kelenjar endokrin seperti diabetes. Pengobatan diabetes tidak hanya membutuhkan perawatan chakra solar plexus yang mengendalikan pankreas, tetapi juga chakra ajna. Pemberian energi kepada chakra ini juga menyebabkan seluruh tubuh diberi energi. Mekanismenya berbeda dari chakra mahkota dan chakra dahi. Pemberian energi kepada chakra ajna tidak menimbulkan efek seperti corong biasa, tetapi menyebabkan chakra lainnya menyala dengan urutan kecepatan tertentu, dengan demikian memberikan energi ke seluruh tubuh. Karena itu dalam penyembuhan menyentuh chakra mahkota, chakra dahi atau chakra ajna penderita dengan jari-jari atau telapak tangan mereka. Kuatnya aliran prana secara mendadak di daerah kepala menyebabkan sebagian penderita kehilangan kesadaran.

\section{Chakra dahi}

Ia terletak dibagian tengah dahi. Tugasnya mengendalikan memberi kelenjar pinel dan sistem syaraf. Gangguan chakra dahi akan bermanifestasi bagai kehilangan daya ingat, kelumpuhan dan sakit ayan (epilepsi). Pemberian energi kepada chakra ini mempunyai pengaruh seperti corong, seperti yang terjadi pada chakra mahkota yang menyebabkan seluruh tubuh dialiri prana.

\section{Chakra mahkota}

Terletak di puncak kepala. Chakra ini mengendalikan dan memberikan energi kepada kelenjar pinel, otak dan seluruh tubuh. Chakra mahkota merupakan salah satu untuk masuk utama prana. Pemberian energi kepada chakra mahkota mempunyai pengaruh seperti pemberian energi ke seluruh tubuh. Hal ini serupa dengan menuangkan air ke dalam corong yang menyebabkan seluruh tubuh dialiri prana. Karena itu beberapa penyembuh memberikan energi kepada chakra mahkota walaupun bagian yang sakit berada ditempat lain. Gangguan fungsi chakra mahkota akan bermanifestasi sebagai penyakit kelenjar pinel dan otak penyakit-penyakit ini dapat bermanifestasi sebagai penyakit fisik ataupun psikologis.

\section{i. Aura \\ Pengertian Aura}

Menurut Joe H. Slate, Ph.D (2002: 12) mendefinisikan bahwa aura adalah kekuatan energi yang mengambangkan dan menyangga hidup manusia yang menjadi karakteristik setiap manusia. Tanpa aura kita tidak mungkin ada. Menurut ilmu pengetahuan setiap benda terdiri dari partikel-partikel kecil yang disebut atom. Atom terdiri dari elektron-elektron yang bermuatan negatif dan proton-proton yang bermuatan positif. Proton dan elektron ini adalah getaran listrik dan magnet. Proton bergerak disekeliling inti, sedangkan elektron bergerak mengelilingi proton. Lapangan dimana atom bergerak disebut lapangan atom energi (energi field). Lapangan energi ini memancarkan cahaya. Dengan demikian setiap benda atau materi yang terdiri dari atom mempunyai lapangan energi bercahaya yang disebut dengan aura. Jadi aura adalah lapangan energi bercahaya yang mengelilingi setiap materi (R. Soegoro, 2001: 42)

Setiap orang memiliki aura, dan dapat belajar dan mengalami aura secara lebih baik. Aura manusia adalah medan energi yang mengelilingi tubuh jasmani yang bersifat tiga dimensi. Pada individunya yang sehat aura membentuk elips atau bulat telur diseluruh tubuhnya bahkan bisa memancar sampai tiga hingga empat meter, semakin sehat jasmani dan rohaninya akan semakin memancar energi orang tersebut dan semakin lebar aura alirannya, semakin kuat aura akan semakin kecil kemungkinan dipengaruhi kekuatan luar. Ada beberapa hal yang menyebabkan aura itu bisa melemah misalnya: Makan yang kurang 
baik, Kurang olah raga, Kurang udara segar, Kurang istirahat, Stress, Minuman alcohol, Obat-obatan terlarang, Tembakau, Kebiasaan buruk, dan Kegiatan jiwa yang tidak tepat.

Aura manusia pada umumnya berubah-ubah tidak tetap, menurut rangsangan batin atau luar. Apapun yang kita ucapkan atau kita lakukan, kita pikirkan akan mempengaruhi medan energi kita. Pancaran energi dari tubuh mencakup medan listrik, magnetik, bunyi panas, cahaya, dan elektromagnetik. Cara yang baik untuk membuktikan bahwa medan energi disekeliling tubuh kita terjalin dengan tubuh jasmaniah dan mempengaruhinya dengan dahsyat yaitu latihan mendorong dan menarik aura. Bentuk, ukuran, warna-warni dan kejelasan warna itu menunjukkan hal-hal istimewa tentang kesehatan jasmaniah, emosional, mental dan spiritual.

\section{j. Warna Dalam Aura}

Warna merupakan bagian akar dari kehidupan kita. Warna mempengaruhi kita semua dalam mencerminkan kesehatan jasmani, suasana hati, sikap dan bahkan pengalaman rohani. Warna merupakan sifat cahaya. Bila warna dipecah-pecah menjadi berbagai panjang gelombang pada akhirnya kita mendapat berbagai macam warna.

Energi sebuah aura menampilkan dirinya sendiri dalam cahaya dan warna. Warna terangnya dan lokasinya semuanya menunjukkan berbagai macam tentang kesejahteraan jasmani dan mental, emosional dan rohaniah seseorang Warna yang berbedabeda mencerminkan sikap, suasana hati dan pola energi yang berbeda-beda pula. Meskipun kita dapat mengindentifikasikan secara umum apa yang kita cerminkan dari warna-warna tertentu kita harus tetap ingat, bahwa ada banyak nuansa dalam spektrum tertentu. Ada banyak nuansa warna kuning, hijau, merah dan sebagainya. Memahami makna nuansa-nuansa ini membutuhkan waktu dan latihan yang relatif lama (tergantung ketekunan).

\section{Latihan Melihat Aura}

Ada dua cara untuk melihat aura secara intuitif dan secara objektif yang keduanya merupakan alat yang baik untuk memahami dalam suatu penglihatan. Secara fisik penglihatan aura tersebut akan menolong menyingkirkan segi keraguan pada kesadaran kita sehingga tidak menjadi penghalang. Dalam metode intuitif aura dapat dilihat dengan mata dan fikiran bukan dengan mata jasmaniah, jika pengindraannya bisa ditafsirkan secara benar. Pengindraan fisik memberi kita kesadaran yang lebih nyata tentang medan energi halus dan secara intuitif persepsi aura lebih gampang ditangkap dari orang lain dari pada diri sendiri.

Sewaktu kita memperkuat otot-otot pada mata terutama pada iris, kita belajar menyesuaikan jumlah cahaya kita melalui pupil, kemampuan ini dapat dikembangkan, sehingga tahap untuk mampu membedakan pencaraan cahaya lembut yang lazim tidak dapat kita tangkap. Latihan denah pada otototot mata akan memperkuat mata kita kearah timbulnya warna yang lebih cerah dan halus.

Latihan untuk melihat warna aura bisa dilakukan oleh diri kita sendiri atau dengan bantuan orang lain, misalnya dengan sendiri kita bisa berdiri di cermin kemudian memandang cermin dengan konsentrasi dan tidak berkedip semampunya dan perhatikan di sisi lapisan eterik pada tubuh kita apabila sering dilakukan dengan tingkat kepekaan tertentu kita dapat melihat warna aura disekeliling tubuh kita terutama di bagian kepala, atau dengan melihat aura orang lain yang ada dihadapan kita, untuk tahap awal konsentrasikan pada sebuah titik yang dibuat atau pada lilin yang berada sekitar satu sampai dua meter dihadapan kita.

\section{PSIKOTERAPI}

\section{Pengertian Psikoterapi}

Menurut Prawitasari (2002:4) istilah psikoterapi berasal dari dua kata yaitu "psiko" dan "terapi". Psiko artinya jiwa atau mental, sedangkan terapi adalah penyambuhan atau usaha, jadi psikoterapi adalah proses formal interaksi antara dua orang atau lebih yang satu adalah profesional yang menolong dan yang satunya lagi yang ditolong, dengan catatan bahwa interaksi itu menuju pada perubahan atau penyembuhan. Perubahan ini dapat berupa 
rasa, pikiran, perilaku, kesehatan, kebiasaan yang ditimbulkan dengan adanya tindakan profesional penolong dengan latar belakang ilmu yang dikembangkan.

Sedangkan menurut M. Hamdani Bakran Adz-Dzaky (2001-219) mendefinisikan bahwa psikoterapi berasal dari bahasa "psyche" dan "therapy". Psyche mempunyai arti diantaranya: Pertama, Jiwa dan hati. Kedua, dalam mitologi Yunani, psyche adalah seorang gadis cantik yang bersayap seperti sayap kupu-kupu, jiwa digambarkan sebagai gadis dan sayap digambarkan sebagai keabadian. Ketiga, Ruh akal dan diri (dzat). Keempat, menurut Froed terdiri dari bagian sadar (concious) dan bagian tidak sadar (unconcius) dan Kelima, dalam bahasa Arab psyche dapat dipadankan dengan nafs.

Dalam beberapa arti secara etimologis tersebut, dapat dipahami bahwa psyche atau nafs adalah bagian dari aspek manusia yang bersifat rohaniah, dan paling tidak lebih banyak menyinggung sisi yang dalam dari eksitensi manusia.

Sedangkan kata "therapy" berasal dari bahasa Inggris berarti pengobatan atau penyembuhan. Sedangkan dalam bahasa Arab berasal dari kata "istisfaa" yang berarti penyembuhan, seperti dalam Al-Qur'an (Yunus, 10:57) yang artinya "Wahai manusia sesungguhnya telah datang kepadamu pelajaran dari Tuhanmu dan penyembuhan bagi penyakit yang ada di dalam dada. dan petunjuk serta rahmat bagi orang-orang yang beriman.

Jadi psikoterapi adalah pengobatan penyakit dengan cara kabatinan atau penerapan teknik khusus pada penyembuhan penyakit mental, atau pada kesulitan penyesuaian diri atau mal ajasment atau penyembuhan pada keyakinan, dan diskusi persialan dengan teman ataupun guru.

Sedangkan Lewis R. Worlberg Mo (1997:222) memberikan definisi pada pesikoterapi yaitu :

"Psikoterapi adalah perawatan dengan menggunakan alat-alat psikologis terhadap permasalahan yang berasal dari kehidupan emosional, dimana seorang ahli secara sengaja menciptakan hubungan profesional dengan pasien, yang bertujuan : (1) menghilangkan, mengubah, atau menemukan gejala-gejala yang ada, (2) memperantai (perbaikan) pola tingkah laku yang rusak, dan (3) meningkatkan pertumbuhan serta perkembangan kepribadian yang positif. Hamdani Bakran (2001:169) lebih lanjut menyebutkan terdapat ciri-ciri yang khas dari psikoterapi di banding dengan yang lainnya.

1. Berpusat pandang pada masa yang lalu dan melihat masa kini individu.

2. Si individu dianggap sakit mental.

3. Si individu dianggap orang yang sakit sehingga terapi tidak akan pernah meminta orang yang ditolongnya itu untuk membantu merumuskan tujuan-tujuan.

4. Terapi berusaha memaksakan nilai-nilai dan sebagainya itu kepada orang yang ditolong.

5. Psikoterapi berpusat pada usaha-usaha pengobatan, teknik-teknik yang dipakai adalah sesuatu dengan yang telah diresepkan.

6. Terapi bekerja dengan dunia dalam diri kehidupan individu yang sedang mengalami masalah berat, psikologi dalam memegang peranan.

\section{Tujuan Psikotrerapi}

Tujuan yang ingin dicapai dalam psikoterafi seperti yang dituturkan oleh Prawitasari (2002:7) meliputi beberapa aspek dalam kehidupan manusia seperti yang tersebut dibawah ini:

1. Memperkuat motivasi untuk melakukan hal-hal yang benar. Tujuan ini biasanya dilakukan melalui terapi yang sifatnya direktif dan suportif, persuasi dengan segala cara dari nasehat sederhana sampai pada hipnotis digunakan untuk menolong orang bertindak dengan cara yang tepat.

2. Mengurangi tekanan emosi melalui kesempatan untuk mengekspresikan perasaan yang mendalam. Fokus disini adalah adanya katarsis, inilah yang disebut dengan mengalami bukan hanya membicarakan pengalaman emosi yang mendalam. Dengan mengulang 
pengalaman ini dan mengekspresiksnnya akan menimbulkan pengalaman baru.

3. Membantu klien mengembangkan potensi melalui hubungannya dengan terapis, klien diharapkan dapat mengembangkan potensinya. Ia dapat mengembangkan diri dari fiksasi yang dialaminya. Ataupun ia akan menemukan bahwa dirinya mampu untuk berkembang kearah yang lebih positif.

4. Mengubah kebiasaan. Terapi memberikan kesempatan untuk perubahan tingkah laku tugas terapetik adalah menyiapkan situasi belajar baru yang dapat digunakan untuk mengganti kebiasaan-kebiasaan yang kurang adaptif. Pendekatan perilaku sering digunakan untuk mencapai tujuan itu.

5. Mengubah struktur kognitif individu. Struktur kognitif menggambarkan idenya, mengenai dirinya sendiri ataupun orang yang ada disekitarnya. Masalah muncul biasanya karena terjadi kesenjangan antara struktur kognitif individu dengan kenyataan yang dihadapinya. Untuk itu struktur kognitif perlu diubah untuk menyesuaikan dengan kondisi yang ada.

6. Meningkatkan pengetahuan dan kapasitas untuk mengambil keputusan dengan tepat. Tujuan ini hampir sama dengan tujuan konseling. Sering terjadi dalam terapi pun isu tentang pengambilan keputusan dan pemecahan masalah akan pula muncul. Untuk itu langkah-langkah seperti dalam konseling dapat dilakukan kombinasi antara kemampuan, keterampilan yang dimiliki klien disesuaikan dengan minatnya untuk menentukan keputusan yang akan diambil.

7. Meningkatkan pengetahuan diri atau insight. Terapi biasanya menuntut individu untuk lebih mengerti tentang apa yang dipikirkan, dirasakan dan dilakukannya. Ia juga akan mengerti mengapa ia melakukan suatu tindakan tertentu. Kesadaran dirinya ini penting sehingga ia akan lebih rasional dalam menentukan langkah berikutnya apa yang dulunya tidak disadarinya menjadi dapat disadarinya sehingga ia mengerti dengan konflik-konfliknya dan dapat mengambil keputusan dengan lebih tepat.

8. Meningkatkan hubungan antar pribadi. Konflik yang terjadi antara manusia biasanya tidak hanya konflik intra personal tapi juga interpersonal. Manusia sejak lahir sampai mati membutuhkan manusia lain, sehingga ia banyak tergantung dengan orang-orang penting dalam hidupnya. Dalam terapi individu dapat melatih kembali untuk meningkatkan hubungannya dengan orang lain sehingga ia akan hidup lebih sejahtera. Ia mampu berhubungan lebih afektif dengan orang lain. Terapi kelompok memberikan kesempatan kepada individu untuk meningkatkan hubungan antar pribadi.

9. Mengubah lingkungan sosial individu. Hal ini dilakukan terutama untuk terapi anakanak. Anak yang bermasalah biasanya hidup dalam lingkungan yang kurang sehat untuk itu terapi ditunjukkan untuk orang tua dan lingkungan yang sosial dimana anak-anak berada. Terapi yang berorientasi pada sistem banyak digunakan untuk memperbaiki lingkungan sosial individu.

10. Mengubah proses somatik supaya mengurangi rasa sakit dan meningkatkan kesadaran tubuh. Latihan-latihan fisik dilakukan untuk meningkatkan kesadaran individu. Latihan relaksasi misalnya bisa digunakan untuk mengurangi kecemasan Latihan Yoga, senam, maupun menari dapat pula digunakan untuk mengendalikan ketegangan tubuh.

11. Mengubah status kesadaran untuk mengembangkan kesadaran, kontrol dan kreatifitas diri. Mengartikan mimpi, fantasi perlu untuk mengerti tentang apa yang dialaminya. Demikian juga meditasi dapat mempertajam pengindraan individu. Tujuan-tujuan terapi di atas biasanya saling terkait satu sama lain. Itu bukan berdiri sendiri. Misalnya latihan tubuh dapat dikombinasikan dengan latihan meditasi. Mengembangkan potensi dapat dikombinasikan dengan pemecahan masalah. 


\section{Terapi Dengan Prana}

\section{Teknik Pengobatan dengan Prana}

Sakitnya tubuh fisik, merupakan manifestasi dari sakitnya tubuh energi. Tubuh energi dikatakan sakit apabila terjadi kekusutan cahaya kesehatan, kebocoran prana akibat rusaknya energi luar, penipisan atau penebalan prana. Hal ini apabila tidak lanjuti secara serius tidak ditindak lanjuti akan mengakibatkan penyakit.

Terdapat enam dasar sebagai pedoman dalam pengobatan prana yaitu:

1. Membuat tangan peka.

2. Menelusuri aura dalam.

3. Menyapu (membersihkan secara umum dan setempat).

4. Meningkatkan kemampuan pasien dengan cara perawatan ini.

5. Pemberian energi yang disalurkan.

6. Pemutusan energi prana yang diproyeksikan.

Pedoman pengobatan prana di atas yaitu dengan rincian sebagai berikut:

\section{a. Membuat tangan peka}

Yang harus dilakukan adalah tekanlah bagian tengah telapak tangan dengan jempol. Tekan juga ujung-ujung jari. Saling gosokkan kedua belah tangan untuk beberapa detik. kemudian getarkan beberapa kali.

1. Saling hadapkan kedua belah tangan dengan jarak kira-kira delapan centimeter. Fokuskan fikiran pada tengah-tengah telapak tangan kira-kira lima sampai sepuluh menit, tarik dan hembuskan nafas perlahan dan berirama. Jangan tegang santai saja.

2. Begitu merasakan sensasi pada telapak tangan, jauhkan secara perlahan kedua belah telapak tangan kemudian kembalikan pada posisi semula. Lakukan gerakan ini beberapa kali. Perhatikan kepekaan telapak tangan selama melakukan gerakan-gerakan tersebut.

3. Latihlah gerakan-gerakan tersebut untuk beberapa hari. Biasanya setelah latihan selama satu bulan, sudah merasakan kepekaan di tangan.
4. Jangan putus asa bila tidak merasakan kepekaan pada awal-awal latihan.

\section{b. Menelusuri aura}

1. Berdirilah dari beberapa kaki dari pasien. Angkatlah kedua telapak tangan dengan telapak menghadap ke pasien.

2. Majulah perlahan dan secara simultan merasakan energi di sekeliling pasien dengan tangan. Fokuskan fikiran pada tengah-tengah tangan. Selama penelitian dalam waktu yang sama, mata hams tertuju pada tubuh pasien yang sedang diteliti.

3. Berhentilah jika tang terasa panas, bergetar atau tidak ada tekanan ringan pada telapak tangan. Ulanglah beberapa kali prosedur tersebut untuk mengkaji ulang apa yang telah dialami dan kenalilah bentuk dan ukuran aura pasien. Sensasi halus yang terasa di tangan adalah energi aura pasien.

4. Untuk aura dalam, mulailah penelitian dengan jarak kira-kira lima belas sampai tiga puluh centimeter dari tubuh pasien. Untuk meneliti cahaya kesehatan, berdirilah kira-kira satu sampai setengah meter dari tubuh pasien. Untuk meneliti aura luar berdirilah 3-4 centimeter dari tubuh pasien.

\section{c. Penyapuan (pembersihan): umum dan setempat}

Penyapuan (sweepings) pada umumnya adalah teknik pembersihan. Penyapuan bisa juga digunakan untuk membagi prana yang berlebihan. Membersihkan seluruh tubuh bioplasmik bisa disebut sebagai penyapuan umum. Penyapuan yang hanya dilakukan pada sebagian tubuh disebut penyapuan setempat.

Prosedur penyapuan memberikan hasil-hasil berikut ini:

1. Menghilangkan kongesti dan bahan bioplasmik berpenyakit. Meridianmeridian yang tersumbat, dan sumbatanya dihilangkan.

2. Racun-racun, kotoran, bakteri dan bahan bioplasmik yang kotor dapat dengan mudah dikeluarkan karena cahaya kesehatan sudah mulai dikuatkan dan dibebaskan dari kekusutan. 
3. Aura kesehatan yang berperan sebagai pelindung sudah dinormalisasi. Hal ini meningkatkan kekebalan tubuh untuk melawan infeksi.

4. Secara otomatis, pembersihan tersebut menutup lubang-lubang aura luar yang menyebabkan prana merembas keluar.

5. Mempermudah penyerapan prana oleh pasien setelah dilakukan penyapuan atau pembersihan.

6. Penyapuan dilakukan untuk mendistribusikan prana yang berlebihan pada bagian yang diobati bagian-bagian tubuh yang telah diberikan energi supaya tidak ada lagi kongesti prana.

7. Reaksi yang mendadak dari pasien dapat dicegah atau dikurangi dengan penyapuan secara tuntas.

8. Penyapuan sangat efektif untuk menurunkan dan menghilangkan demam. Penyapuan umum dilakukan dengan serangkaian gerakan menyapu kebawah dan hanya menggunakan tangan. Ada dua posisi tangan yang digunakan penyapuan: posisi tangan tertutup dan posisi jari terbuka. Posisi telapak tangan tertutup lebih efektif untuk membuang bioplasmik yang tidak sehat sedangkan posisi jari-jari yang direntangkan terbuka lebih efektif untuk menyisir dan membebaskan kekusutan cahaya kesehatan. Penyapuan umum juga bisa disebut pembersihan aura.

\section{d. Prosedur penyapuan umum:}

1. Langkah kedua tangan dalam posisi tengkurap dan letakkan kurang lebih 15 centimeter diatas kepala pasien. Tidak perlu menyentuh kepala pasien. Jagalah jarak kira-kira $5 \mathrm{~cm}$ antara pasien dan kedua tangan.

2. Dengan posisi tangan yang masih dilengkupkan, ayunkan tangan dengan perlahan di kepala sampai ke bawah ujung kaki. Kemudian, kibaskan kedua tangan untuk membebaskan kekusutan cahaya kesehatan dan ini bisa disebut sebagai penyisiran.

3. Ulangi langkah (b) diatas, dengan posisi jari-jari tangan yang direntangkan terbuka mengganti posisi tangan yang dilengkungkan. Cara ini untuk membebaskan kekusutan cahaya kesehatan dan ini bisa disebut sebagai penyisiran.

4. Ulangi langkah (b) dan (c) diatas.

5. Lakukanlah prosedur penyapuan umum pada pasien dengan menggunakan langkah (b), (c), dan (d) diatas.

6. Sangat penting sekali untuk berkonsentrasi dan menginginkan supaya bahan bioplasmik yang kotor, terbuang. Hanya dengan keinginan atau pemusatan pikiran dan dibantu dengan kedua telapak tangan, bahan bioplasmik yang kotor dapat dibersihkan secara menyeluruh dan cepat.

7. Setelah penyapuan kebawah dilakukan, biasanya ada beberapa pasien yang mengantuk. Kita boleh menerapkan beberapa gerakan penyapuan keatas supaya pasien terbangun atau lebih waspada. Peringatan: jangan melakukan penyapuan keatas kecuali penyapuan kebawah sudah selesai dan pasien sudah bersih, penyapuan keatas bisa mengakibatkan bioplasmik dibagian kepala kemudian memberi efek negatif pada tubuuh pasien.

\section{Penyapuan setempat:}

1. Letakkan satu atau dua tangan di depan bagian tubuh yang sakit, berkonsentrasi pada tangan atau pada bagian tubuh yang sakit, kemudian sapu keluar bagian tubuh bioplasmik yang kotor. Ini seperti membersihkan benda yang kotor dengan tangan.

2. Kibaskan tangan sekuat-sekuatnya untuk membuang bahan bioplasmik yang kotor.

3. Gerakan penyapuan bisa diarahkan kemana saja : tegak, lurus, diagonal, atau berbentuk huruf L.

4. Untuk penyakit yang sederhana, lakukanlah setempat sebanyak 20-30 kali pada bagian tubuh yang sakit. Cara ini berguna sekali untuk menyembuhkan sakit perut, misalnya menstruasi, (dysmenorrhea), diarae, sakit kepala dan lain-lain,

5. Untuk penyakit kronis, frekuensi penyapuan setempat harus bertambah. 
Untuk kista, lakukan penyapuan setempat sebanyak 50 kali: untuk hepatitis yang parah, kira-kira lakukan seratus kali atau lebih karena di bagian tersebut sudah terjadi peradangan.

Adakalanya selama penyapuan setempat, bioplasmik berpenyakit dari bagian tubuh yang kena ke bagian lain. Misalnya, ada seorang pengobat menyapu bioplasmik yang menyumbat di bagian kepala pasien., sebagian dari bagian bahan tersebut pindah kebagian leher dan bahu. Ini mengakibatkan sakitnya berpindah, apabila menemukan seperti ini segera lakukan penyapuan disekitar yang sakit.

Benda bioplasmik yang kotor harus dibuang secara tepat supaya kebersihan ruangan terpelihara dan kita sebagai pengobat atau terapi tidak tertular dengan bahan bioplasmik. Tempat pembuangan bioplasmik yang kotor disediakan dengan mengisi satu liter air yang dicampur dengan dua atau tiga sendok makan garam, dalam sebuah mangkok atau ember kecil, karena sudah terbukti bahwa air garam dapat menyerap bahan bioplasmik yang kotor.

Setiap habis menyapu atau membersihkan kita harus mengibas tangan pada mangkuk tersebut. Dalam keadaan darurat dimana mangkuk, air dan garam tidak ada. Bayangkan atau imajinasikan ada bola api berwarna hijau yang menyala disamping kita kemudian buang bahan bioplasmik yang kotor itu kedalam bola api tersebut kemudian padamkan bola apinya apabila sudah selesai.

\section{Meningkatkan daya penerimaan pasien}

Penyembuhan akan menjadi sangat mudah bila pasien bisa santai dan pasrah tanpa melakukan perlawanan apapun. Jika pasien sanati, ia akan lebih banyak menerima energi prana. Disarankan untuk menciptakan hubungan yang baik dengan para pasien guna menghindari perlawanan. Hubungan tersebut bisa diciptakan antara lain dengan memberikan senyum pada pasien pada pertemuan pertama, atau menciptakan good raport serta memperkuat pasien dengan baik dan sopan. Untuk meningkatkan daya penerimaan persilahkan pasien untuk dengan posisi kedua telapak tangan menghadap keatas, mata tertutup dan kepala sedikit ditundukan kebawah. Dan untuk pasien yang ragu-ragu mintalah untuk berdoa di dalam hati.

\section{Memberikan energi prana yang disalurkan, teknik chakra tangan}

Kedua belah tangan adalah alat yang paling penting dalam pengobatan prana. Kedua tangan ini dipakai untuk menerima dan menyalurkan prana kepada pasien, ditengah-tengah telapak tangan terdapat chakra minor dan diujungujung jari juga terdapat chakra yang lebih kecil atau chakra mini. Pemberian energi bisa dilakukan apabila seluruh tubuh atau sebagian dari tubuh atau organ sudah dibersihkan. Bila memproyeksikan prana ke tubuh bioplasmik pasien, pengobatan secara bersamaan hams menarik prana udara atau butir-butir vitalitas disekitamya. Cara ini dilakukan untuk mencegah terkurasnya atau habisnya prana pengobatan sendiri dan menjadi rentan terhadap penyakit dan infeksi.

Untuk latihan menarik prana yaitu dengan berkonsentrasi pada bagian tengah telapak tangan yang menerima prana selama 5-10 menit tank dan hembuskan nafas secara berirama. Kita juga boleh membayangkan cahaya putih yang turun dari atas masuk kedua telapak tangan. Mungkin terasa panas, perih dan ada getaran. Ini berarti tangan sudah peka terhadap prana yang mengalir kearah chakra tangan. Ulangi latihan ini beberapa kali untuk mengembangkannya.

Sedangkan untuk latihan memproyeksikannya prana dengan berkonsentrasilah pada bagian tengah telapak tangan yang menerima prana selama 5-10 menit, tank dan hembuskan nafas secara perlahan dan bayangkan cahaya putih keluar dari telapak tangan. Mungkin akan terasa sedikit panas atau ada udara yang keluar dari telapak tangan dan jari-jari. Ulangi latihan ini untuk mengembangkan kemampuan memproyeksikan prana.

Pengobatan prana dan pasien dihubungkan dengan tali energi (tali cahaya). Karena tali inilah yang bisa menyebabkan kembali energi yang telah diproyeksikan kepada terapi sehingga pasien lebih lambat sembuh dari yang 
diharapkan. Sementara itu jika pasien sangat kekurangan prana, ada kemungkinan bahwa terapis atau pengobatan tidak mengetahui dan secara tidak disadari melanjutkan proses pemberian energi yang berkepanjangan, sehingga mengakibatkan pengobatan kehabisan prana. Untuk menghindari dari hal demikian, pengobatan harus memvisualisasikan bahwa sedang memotong tali energi atau tali cahaya tersebut dengan gunting atau pisau.

\section{Faktor-faktor penyembuhan penyakit}

Untuk mengerti tentang penyakit, orang harus mempertimbangkan faktor internal dan faktor eksternal dari penyebab datangnya penyakit. Faktor eksternal berarti faktor fisik yang ikut berperan yang menyebabkan timbulnya penyakit. misalnya dari kuman, gizi yang salah, zat beracun, polusi, kurang berolah raga. kurang minum, pola hidup tidak sehat, lingkungan kotor dan sebagainya. Sedangkan faktor internal disebabkan oleh penyakit emosi yang negatif, stress, meridian tertutup, penipisan prana dan kongesti prana, gangguan fungsi chakra dan sebagainya. Misalnya faktor emosional dapat menyebabkan melemahnya chakra solar plexus dan hati, dan serangan virus akan mengakibatkan peradangan hati. Faktor eksternalnya adalah virus sedangkan vaktor internalnya adalah emosi negatif dan melemahnya chakra solar plexus dan hati yang menyebabkan hati mudah diserang penyakit. Jika orang yang mempunyai vitalitas yang tinggi kemungkinan terkena penyakit lebih kecil. Mekanisme pertahanan dan sistem detoksinasi dan sistem pembersihan pada tubuhnya kemungkinan besar dapat menanggulangi virus atau zat racun tersebut. Tetapi faktor internal saja yang berlebihan. Misalnya orang yang sedang marah dengan berlebihan dan frustasi dapat menyebabkan kongesti prana hebat di sekitar chakra solar plexus dan akhirnya pada jantung. Walaupun ia telah menjaga pola makannya tetap saja ia beresiko pembengkakan pada jantung.

\section{TENAGA PRANA SEBAGAI TERAPI ALTERNATIF BAGI PENYEMBUHAN PENYAKIT PASIEN}

Pada saat ini yang menggunakan metode terapi dengan Tenaga Prana adalah Klinik pengobatan yang ada di Jl.Buah Batu Bandung yang di pimpin oleh Bapak H.Nana Sumarna dengan Yayasan Majlis Taklim Al-Ukhuwah Bandung. (Majalah Man, 26 : 2002).

Untuk memantapkan kemampuan H. Nana Sumarna berguru ke Negeri Cina selama dua tahun dan ke Filipina selama tiga tahun dari semenjak tahun 1992-1995. Walaupun beliau sebelumnya telah memiliki bakat yang diturunkan dari ayahnya yang suka mengobati orang yang gila atau sizofrenia. (Hasil wawancara dengan H. Nana Sumarna di Klinik Pengobatan pada tanggal 22 September 2002).

Beliau cukup dikenal di dunia perguruan terutama tenaga dalam yang ada di Indonesia khususnya di masyarakat Jawa Barat karena beliau pernah menjabat sebagai Ketua Prana sejak tahun 1995 sampai sekarang yang bertempat di lantai dua Gramedia.

Pasien yang berobat ke Klinik pengobatan bermacam-macam keluhan penyakit yang di derita dari yang ringan, penyakit kejiwaan, sampai yang berat seperti : Penyakit Maag, Batu Ginjal, Jantung, Kanker, Panas, Stres, Asam urat, dan lain-lain. Ada yang khusus diobati dengan prana saja atau di satukan dengan pengobatan lainnya seperti : dengan akupuntur, akupreasure, sengat lebah, refleksi kaki atau dengan reiki.

\section{Teknik Tenaga Prana Terhadap Penyakit Pasien Yang di Derita}

Teknik tenaga prana yang digunakan pada penyakit pasien disesuaikan dengan jenis penyakitnya diantaranya adalah :

Penyakit Maag

Telusuri bagian depan dan belakang chakra solar plexus, chakra pusar dan daerah perut. Lakukanlah penyapuan umum. Lakukanlah penyapuan setempat dengan seksama pada bagian depan chakra solar plexus, chakra pusar dan bagian perut. Dalam banyak kasus, gejalagejala akan banyak berkurang dengan penyapuan yang seksama. Aktifkan energi 
pada chakra solar plexus dan bagian perut. Jika penyapuan setempat tidak dilakukan dengan seksama, pasien bisa mengalami reaksi yang memperburuk keadaannya. Mantapkanlah energi prana yang diproyeksikan.

\section{Batu Ginjal}

Telusuri pasien lalu lakukan penyapuan setempat pada chakra meng mein, lakukan penyapuan pada solar plexus depan dan belakang dan beri energi dengan hijau muda keputih-putihan dan oranye muda keputihputihan, lakukan penyapuan setempat pada urete kalau ia terganggu. Untuk menghancurkan batu-batunya secara berangsur, beri energi secara langsung ginjal yang terganggu itu dengan warna biru muda keputih-putihan, hijau muda, lalu oranye muda. Biru adalah untuk melokalisasi, hijau dan oranye efektif untuk melarutkan dan menghancurkan.

Untuk pengeluaran batu ginjal, risleting pasien di buka dan (maaf) penisnya (bila pasiennya laki-laki) di keluarkan. Untuk membantu pengeluaran batu ginjal dan mengetahui posisi batu ginjal dalam saluran kencing, kita juga bisa menggunakan kateter yang dimasukkan ke dalam saluran kencing. Kalau batu ginjalnya berukuran besar, maka pengobat dapat menghancurkan atau memecah batu itu agar ketika di keluarkan tidak terlalu sakit.

Peganglah batang penis pasien dengan tangan kiri dengan menggunakan sarung tangan plastik. Hal ini dimaksudkan untuk menghindarkan dari kontak langsung, terutama jika pasien mengidap penyakit menular. Kemudian niatkan dalam hati pengobat untuk menarik batu ginjal dengan menyalurkan prana keputih-putihan. Suruhlah pasien untuk duduk dan mengambil sendiri dari kemaluannya. Pengeluaran ini bisa terjadi beberapa kali tergantung jumlah batunya. Ketika pengeluaran terjadi pasien akan merasakan kesakitan, itu adalah hal yang biasa.

Setelah batu itu keluar dari tubuh pasien, pengobat melakukan pemantapan energi dengan cara menyalurkan energi dengan prana hijau muda keputih-putihan dan oranye muda keputih-putihan pada chakra meng mein, chakra minor ginjal, dan chakra seks. Kemudian berilah energi pada chakra solar plexus depan dan belakang, chakra pusar.

Stabilkan dan lepaskan energi prana yang diproyeksikan, ulangi perawatan prana beberapa kali sehari untuk beberapa hari berikutnya.

Penyakit Asma

Penyakit asma ada yang berasal dari fisik dan biasanya proses penyembuhannya lebih cepat dan adakalanya dari emosional, maka laju penyembuhannya biasanya memakan waktu lebih lama, pasien harus melepaskan emosi-emosi yang terpendam.

Telusuri pasien, lalu lakukan penyapuan umum dua kali. Lakukan penyapuan setempat dengan seksama pada chakra tenggorok dan chakra minor sekunder. Chakra minor tenggorokan sekunder terletak pada bagian bawah tenggorokan yang lunak. Beri energi dengan hijau muda keputih-putihan kemudian dengan merah muda keputih-putihan. Prana merah mengandung efek memperbesar pembuluh udara. Lakukan penyapuan setempat pada paru-paru dengan hijau muda keputihputihan, kemudian oranye muda keputihputihan, lalu oranye muda keputih-putihan. Prana oranye mempunyai efek mengeluarkan yang akan mempercepat efek memperlebar dan memperkuat prana merah, jika langkah diatas dilakukan dengan benar maka gejala-gejala akan di kurangi dengan cepat. Lakukan penyapuan setempat pada solar plexus depan dan belakang dan pada hati beri energi dengan prana lembayung biasa.

Untuk penyembuhan pasien secara berangsur-angsur dan tetap bersihkan chakra dasar dan beri energi dengan prana merah muda keputih-putihan, bersihkan chakra azna dan beri energi dengan hijau muda dan lembayung. Untuk meningkatkan kualitas darah yang dihasilkan, lakukan penyapuan setempat pada lengan dan tungkai. Beri energi dengan chakra minor telapak kaki dengan prana merah muda. Visualisasikan energi prana memasuki tulangtulang punggung.

Stabilkan dan lepaskan energi prana yang diproyeksikan. Ulangi perawatan tiga kali 
seminggu selama sekitar satu dua bulan. Jika perawatan dilakukan dengan benar, gejalagejala akan cepat berkurang. Penyembuhan prana sangat efektif untuk menyembuhkan asma.

\section{Penyakit Influenza dan Bronkitis}

Telusuri pasien, lakukan penyapuan umum sebanyak dua kali. Lakukan penyapuan lokal pada setempat pada solar plexus depan dan belakang dan pada hati, pada jantung depan dan belakang, pada paru-paru, pada chakra ajna, tenggorokan dan tengorokan sekunder, penyapuan pada chakra limpa yang di beri energi prana putih, penyapuan pada chakra pusar dan dasar kemudian diberi energi dengan hijau muda keputih-putihan, biru muda, hijau muda, lembayung.

Lakukan penyapuan setempat pada chakra minor tangan dan telapak tangan beri energi lembayung. Visualisasikan energi prana sebagai memasuki tulang-tulang. Ini untuk merangsang sistem pertahanan tubuh. Ulangi beberapa kali dalam sehari. Stabilkan dan lepaslan energi prana yang diproyeksikan. Darah Tinggi (hypertension)

Lakukan penyapuan umum sebanyak tiga kali atau lebih. Lakukan penyapuan setempat pada chakra mahkota, yang berada di bagian belakang kepala dan pada tulang punggung, sampai pasiennya merasa nyaman sekali. Lakukan penyapuan setempat pada chakra solar plexus dan chakra meng mein sebanyak 50 kali atau lebih sampai tensi darahnya menjadi turun dan normal kembali, dan diulangi beberapa kali bila perlu. Lakukan penyapuan lokal pada chakra dasar karena biasanya bagian ini juga dapat terkena. Lakukan penyapuan setempat pada chakra pada chakra mahkota, chakra dahi, dan ajna, kemudian lakukanlah penyapuan pada bagian itu lebih banyak.

\section{Penyakit Jantung}

Telusuri jantung dengan seksama. Mintalah pasien untuk menunjukkan daerah yang sakit, lakukanlah penyapuan pada chakra jantung depan dan daerah kecil yang bermasalah dengan jari anda. Visualisasikan bahwa jari anda memasuki daerah tersebut untuk menghilangkan bahan bioplasmik berpenyakit. Jantung harus diberi energi melalui chakra jantung depan Visualisasikan bahwa jantung fisik dan chakra jantung menjadi terang setelah dilakukan penyapuan. Yang menjadi perhatian utama adalah pemberian energi akan tetapi pembersihan dengan seksama juga sangat penting. Lakukan penyapuan setempat dengan seksama pada chakra hati dan solar plexus.

Jika pasien lemah penyapuan uraum harus dilakukan terlebih dulu sebelum langkah pengobatan lainnya agar cahaya kesehatan dapat diluruskan dan lubang-lubang di aura luar dapat ditutup. Lakukanlah pembersihan setempat dan salurkan energi pada chakra dasar dan chakra pusar. Langkah ini akan menguatkan tubuh dan proses penyembuhan menjadi cepat.

\section{Penyakit Stroke}

Perawatan stroke karena penyumbatan pembuluh darah otak yang pertama dilakukan, Penelusuran pasien terutama pada chakra mahkota, chakra dahi, chakra ajna, chakra minor belakang kepala, chakra minor rahan, chakra tenggorokan, chakra minor tenggorokan sekunder, chakra solar plexus hati, chakra dasar, telusuri kembali pasien selama perawatan. Lakukan penyapuan umum selama tiga kali atau lebih.

Lakukan penyapuan setempat pada yang terganggu dan pada sepuluh bagian kepala secara bergantian, lakukan penyapuan setempat pada seluruh bagian leher, tulang punggung, paru-paru, pada jantung depan dan belakang, chakra dasar, chakra sex, atau pada seluruh chakra apabila chakra itu terganggu. Kemudian beri energi pada chakra-chakra yang terganggu dengan warna hijau muda, lembayung, biru dan oranye.

Stabilkan dan lepaskan energi yang diproyeksikan. Ulangi perawatan tiga kali seminggu. Pasien diharapkan menjalani perawatan terapi fisik sebagai pelengkap. Hasilnya akan sangat bervariasi ada yang sembuh dengan cepat dan ada yang lambat.

\section{Stress}


Lakukan penelusuran pada pasien, lakukan penyapuan umum sebanyak tiga kali, lakukan penyapuan setempat pada chakra mahkota, chakra ajna chakra jantung dan chakra solar plexus kemudian beri energi dengan prana hijau muda keputih-putihan, prana biru muda, prana oranye muda keputih-putihan. Telusuri kembali pasien untuk distabilkan dan lepaskan energi yang diproyeksikan. Ulangi perawatan tiga kali dalam seminggu untuk lebih cepat penyembuhan sebaiknya pasien diberikan terapi konseling dan menjauhi pada hal-hal yang membuat dia stres atau berikan tips-tips agar dia kuat ketika menghadapi stressor. Sakit menstruasi.

Telusuri pasien, lalu telusuri kembali selama perawatan prana. Lakukan penyapuan setempat pada chakra seks secara berganti-ganti dengan prana hijau muda keputih-putihan dan dengan prana oranye keputih-putihan. Jika pembersihan dilakukan dengan benar. Rasa sakit dapat segera berkurang.

Beri energi chakra seks dengan warna putih. Lakukan penyapuan setempat pada chakra dasar, dan chakra pusat dan beri energi dengan warna putih. Jika pasien telah terkuras dan pingsan, lakukan penyapuan setempat dengan seksama pada chakra solar plexus dan beri energi dengan prana merah muda keputihputihan. Stabilkan dan lepaskan energi prana yang diproyeksikan. Perawatan bisa dilakukan tiga hari sebelum haid untuk mencegah (dismenore) nyeri haid.

\section{Sakit mata}

Sakit mata karena infeksi yaitu dengan melakukan penyapuan setempat pada bagian yang sakit secara berganti-ganti dengan hijau muda keputih-putihan. Lakukan penyapuan setempat pada chakra ajna dan chakra minor belakang kepala. Berilah energi kepada kedua tempat ini dengan hijau muda keputih-putihan, biru muda keputih-putihan kemudian dengan lembayung keputih-putihan biasa. Visualisasikan energi prana masuk kedalam mata. Lakukan lebih banyak penyapuan setempat pada mata.

\section{Kista atau benjolan}

Telusuri pasien, lakukan penyapuan umum, lakukan penyapuan setempat pada chakra seks, daerah sekitarnya dan indung telur daerah yang terganggu berganti-ganti dengan hijau muda keputih-putihan dan dengan oranye muda keputih-putihan. Beri energi indung telur yang terganggu dengan biru muda keputih-putihan. lalu dengan hijau muda dan dengan oranye muda untuk membersihkan. Biru adalah untuk melokalisasi dan hijau untuk menghilangkan kongesti dan untuk melarutkan.

Lakukan penyapuan pada chakra dasar dan chakra pusar, beri energi putih. Lakukan penyapuan setempat dengan seksama pada chakra mahkota, ajna dan chakra tenggorok. Beri energi dengan hijau muda keputihputihan. Stabilkan dan lepaskan energi prana yang diproyeksikan. Untuk perawatan tiga kali seminggu . Ulangi perawatan tersebut. Stabilkan dan proyeksikan energi yang dihasilkan. Ulangi perawatan tiga kali seminggu. Perawatan akan memakan waktu tiga bulan atau lebih.

\section{Penyakit Diabetes}

Telusuri pasien lalu lakukan penyapuan umum dua kali. Lakukan penyapuan setempat pada chakra solar plexus depan dan belakang, hati dan pankreas. Beri energi chakra solar plexus belakang dan pangkreas dengan hijau muda keputih-putihan, biru muda, lalu dengan lembayung muda keputih-putihan biasa. Lakukan penyapuan setempat dengan seksama pada chakra ajna. Beri energi dengan hijau muda keputih-putihan, lalu dengan lebih banyak lembayung muda keputih-putihan biasa. Lakukan penyapuan setempat pada chakra meng mein, lakukan penyapuan pada ginjal dengan hijau muda keputih-putihan berganti-ganti dengan oranye muda keputihputihan. Lakukan penyapuan setempat pada chakra dasar dan chakra pusat. Beri energi merah muda. Lakukan penyapuan setempat pada chakra jantung depan dan belakang. Beri energi chakra jantung belakang dengan lebih sedikit hijau muda keputih-putihan, lalu dengan lebih banyak lembayung muda biasa. Lakukan penyapuan pada chakra tenggorokan, 
chakra dahi, chakra mahkota dan chakra minor belakang kepala. Beri energi dengan hijau muda keputih-putihan lalu dengan lebih banyak lembayung muda keputih-putihan. Stabilkan dan lepaskan energi prana yang diproyeksikan. Ulangi perawatan dua kali seminggu.

\section{Kanker}

Pada kasus kanker, chakra-chakra yang terganggu adalah : Chakra dasar terlalu giat, terkuras, dan dipenuhi energi berpenyakit merah kuning kotor atau dengan energi berpenyakit merah kotor. Chakra meng mein terlalu giat dan terkuras dipenuhi energi berpenyakit merah kuning kotor, chakra solar plexus terlalu giat, mengalami kongesti, dan dipenuhi energi berpenyakit merah kuning kotor atau energi berpenyakit merah kotor. Chakra jantung kurang giat, terkuras dan dipenuhi energi berpenyakit merah kuning kotor atau energi merah kotor. Chakra ajna kurang giat terkuras dan dipenuhi energi merah kuning kotor. Terapi yang dilakukan yaitu dengan cara skeanning atau penelusuran pada penyakit kemudian dilakukan penyapuan umum dan setempat dan pemberian energi pada chakra yang terkuras, nan sakit, memproyeksikan energi kemudian pemutusan energi. Limbah bioplasmik yang kotor di buang pada air garam.

\section{Retardasi (keterbelakangan) mental}

Telusuri pasien, lakukan penyapuan umum dua kali, lakukan penyapuan setempat secara bergantian dengan prana dengan hijau muda dan dengan prana lembayung muda pada seluruh kepala. Chakra mahkota, chakra dahi, chakra ajna, chakra minor belakang kepala, chakra minor rahang, chakra tenggorok dan chakra minor tenggorok sekunder. Ini harus dilakukan dengan seksama. Beri energi chakra tersebut dengan hijau muda keputih-putihan lalu dengan lebih banyak lembayung rnuda. Lakukan penyapuan setempat pada chakra jantung depan dan belakang dan chakra solar plexus depan dan belakang dengan putih. Lakukan penyapuan setempat pada chakra pusat dan chakra seks serta chakra dasar dengan seksama beri energi dengan warna hijau muda dan oranye keputih-putihan.

Stabilkan dan lepaskan energi yang diproyeksikan. Ulangi perawatan tiga kali seminggu selama beberapa tahun berikutnya. Perawatan prana harus dilengkapi dengan pendidikan khusus.

\section{Amandel}

Lakukan penyapuan setempat pada chakra minor rahang, dan chakra tenggorok serta chakra minor tenggorok sekunder bergantiganti dengan hijau muda dan lembayung muda keputih-putihan. Pembersihan harus dilakukan dengan seksama. Berilah energi kepada chakra minor rahang, chakra tenggorok, dan chakra tenggorok sekunder dengan hijau muda, biru muda dan lembayung muda keputih-putihan biasa.

\section{Panas Demam}

Telusuri seluruh tubuh terutama pada chakra-chakra mayor, organ-organ vital dan tulang punggung. Orang yang menderita demam umumnya mengalami penipisan prana. Aura agak menciut dan terjadi kongesti pada chakra solar plexus. Lakukanlah penyapuan umum tiga sampai lima kali pada seluruh tubuh. Lakukanlah penyapuan setempat pada chakra solar pleksus depan dan belakang kirakira tiga puluh kali atau lebih kemudian salurkanlah energi pada solar plexus. Mantapkanlah energi prana yang diproyeksikan. Pada bayi dan anak-anak lakukan saja penyapuan umum dan setempat pada bagian depan dan belakang chakra solar plexus. Penyembuhan ini bisa diulang untuk beberapa kali dalam sehari apabila diperlukan.

\section{Faktor-faktor yang Menunjang Proses Penyembuhan Pasien}

Faktor yang paling utama dalam proses penyembuhan adalah terapis dengan pasiennya sendiri, dimana keduanya harus terjadi proses interaksi mutualisme atau saling mendukung, dua-duanya harus sama-sama ikhlas dalam diobati dan mengobati. Sugesti sangat dominan mempengaruhi kesehatan. Pengobat atau 
terapis juga harus memiliki keahlian dalam penyembuhan yaitu dengan mengetahui dan mempelajari seni penyembuhan tenaga prana sebelum mengobati.

Pengobatan dengan prana juga memerlukan kesabaran karena sistem pengobatan ini menggunakan energi terhalus dari manusia sehingga hal ini sulit dirasakan bagi orang yang tidak peka, juga memerlukan pengobatan secara kontinue. Seorang pengobat prana yang terlatih dan berpengalaman dapat mengetahui berapa kali sebaiknya pasien dapat diobati. Jika penyakit pasien parah, pengobatan harus lebih sering dilakukan. Ada beberapa penyakit yang membutuhkan pengobatan setiap tiga jam sekali, luka bakar diobati tiap satu jam sekali. Kanker diobati setiap dua hari sekali, juga terdapat banyak kasus pasien mesti diobati tiga kali seminggu.

Kondisi terapis harus dalam kondisi fit atau sehat tidak dalam kondisi lemah atau kecapaian, karena mengobati dengan prana itu menguras energi yang banyak dari pengobatnya sendiri, jika salah teknik atau kondisi badan lemah bisa-bisa penyakit pasien bisa berbalik kepada pengobatnya sendiri.

Tubuh fisik biasanya terdapat jeda waktu (lag time) dalam merasakan kesembuhan. Kesembuhan mungkin saja memerlukan waktu beberapa jam, bahkan bisa satu hingga dua hari karena dipengaruhi oleh beberapa faktor yaitu :

a. Banyaknya frekwensi sesi pengobatan.

b. Umur dan kondisi fisik pasien.

c. Tingkat kemampuan menerima pasien.

d. Kehadiran beberapa gangguan yang mengakibatkan keterlambatan penyembuhan

e. Tingkat kerusakan pada tubuh fisik

f. Sifatnya penyakit.

g. Kemampuan dari pengobat prana.

h. Penerimaan dan tingkat kerja sama dari pasien.

\section{Faktor-faktor yang Menghambat Proses Penyembuhan Pasien}

Beberapa alasan mengapa pasien tidak sembuh yaitu: Kemungkinan pasien tidak menerima pengobatan prana dengan benar. karena penelusuran yang dilakukan tidak tepat. Misalnya pasien yang kesulitan menggerakkan lengannya mungkin saja disebabkan karena kongesti prana pada chakra jantung dan chakra solar plexus atau kongesti prana pada chakra meng mein. Inilah sebabnya pengobatan pada lengan akan memberikan penyembuhan sementara saja, tapi hasilnya tidak memuaskan.

Pemberian energi dari frekwensi pengobatan prana diberikan tidak memadai, hal ini seperti memberi obat yang dosisnya sedikit dalam waktu yang jarang. Ada beberapa penyakit yang memerlukan cara pengobatan yang lain, contohnya adalah kekurangan gizi dan diet yang salah.

Pasien yang lanjut usia atau yang sudah lemah atau yang sangat parah penyakitnya. Ada beberapa faktor yang tidak bisa di jelaskan misalnya memiliki prana yang sedikit. Ini tidak berarti bahwa mereka diabaikan atau di kesampingkan, tetapi harus di beri pengobatan dan operawatan yang ekstra.

Banyak pasien yang menderita penyakit kronis umumnya menyimpan perasaan negatif dalam waktu yang lama. Contohnya seorang pasien yang menderita pengerasan hati (cirrhosis). Meskipun pasien tidak minum minuman beralkohol. Pasien yang bertemperamental buruk dan seringkali memaki-maki orang padahal masalahnya sepele. Karena perasaan negatif tersebut, chakra solar plexusnya tidak berfungsi dan itu berakibat pada penyakit hati.

Stress juga mempengaruhi pada chakra solar plexus dan hati serta dalam beberapa tingkatan pada kolesterol tubuh. Untuk itulah disarankan kepada pasien yang memiliki penyakit parah supaya memiliki perasaan dan sifat positif serta belajar meditasi sederhana.

\section{E. KESIMPULAN}

Penyembuhan pranik atau penyembuhan dengan tenaga prana merupakan penyembuhan yang menggunakan energi vital untuk menyembuhkan tubuh fisik. Dengan prana juga melibatkan manipulasi ki dan bahan 
bioplasmik tubuh penderita. Cara penyembuhan seperti ini sering pula penyembuhan psikis, penyembuhan magnetik, penyembuhan kepercayaan, penyembuhan vitalik, sentuhan terapeutik dan penyembuhan kharismatik.

Teknik-teknik yang digunakan di Klinik pengobatan Alternatif Buah Batu Bandung ini, yang merupakan ciri khas yaitu dengan menggunakan tenaga prana telah membuktikan keberhasilannya di dalam menyembuhkan penyakit pasien. Sebanyak $26 \%$ pasien mengalami kesembuhan dan pasien yang mengalami perubahan kearah kesembuhan sebanyak $76 \%$, pasien tersebut proses penyembuhannya belum tuntas atau dosisnya belum mencukupi dan di perlukan terapi dengan tenaga prana lebih sering lagi secara kontinue untuk mendapatkan hasil yang maksimal.

Teknik-teknik prana yang digunakan itu dengan menggunakan telapak tangan, mengaktifkan chakra minor di tangan. Hal pertama yang dilakukan yaitu proses scanning atau penelusuran atau pemeriksaan pada tubuh pasien. Kemudian melakukan proses penyapuan pada tubuh pasien baik penyapuan umum atau penyapuan setempat atau lokal untuk membuang energi kotor, terjadi penumpukan energi yang disebut dengan kongesti prana. Hal ketiga yang dilakukan adalah pemberian energi dengan tenaga prana terutama pada chakra-chakra yang terkena penyakit dan bisa menggunakan warna prana bila sudah mampu seperti warna biru muda, lembayung muda keputih-putihan, oranye muda dan lain-lain pada tubuh yang sakit. Kemudian lakukan proses penelusuran kembali dan menstabilkan kondisi fisik dan memproyeksikan prana kemudian proses akhir adalah pemutusan tenaga prana yang diproyeksikan. Teknik-teknik inilah yang digunakan di Klinik Pengobatan Alternatif di Buah Batu Bandung.

Tenaga prana sebagai salah satu terapi alternatif cukup efektif dalam proses penyembuhan penyakit pasien dengan tanpa efek samping yang membahayakan bagi jiwa pasien (hasil wawancara dan penyebaran angket pada 50 responden di klinik pengobatan Buah Batu Bandung).

\section{F. DAFTAR PUSTAKA}

Akbar S Ahmad, 1993, Post Modernisme, Bahaya dan Harapan Bagi Islam, Mizan, Bandung

Al-Ukhuwah,2001, Seni Tenaga Dalam AlUkhuwah, Kumpulan Diktat, Bandung.

Ari Nugraha Wirson,

2001, Senam Sehat Prana, Kiblat, Bandung.

Cik Hasan Bisri, 2001, Penuntun

Penyusunan Rencana Penelitian dan Penulisan Skripsi, PT Raja Grafindo Persada, Jakarta.

Choa Kok Sui, 1998, Ilmu dan Seni Penyembuhan dengan Tenaga Prana, Panduan Praktis Langkah Demi Langkah, Elex Media Komputindo, Jakarta.

Choa Kok Sui, 2000, Ilmu Dan Seni Penyembuhan dengan Tenaga Prana, Gramedia, Jakarta

Choa Kok Sui, 2001, Penyembuhan Tenaga Prana Tingkat Lanjut, Gramedia, Jakarta.

Choa Kok Sui, 2000, Psikoterapi Prana, Gramedia, Jakarta.

Dadang Kahmad, 2000, Metode Penelitian Agama, Pustaka Setia, Bandung.

Depdikbud, 1997, Kamus Besar Bahasa Indonesia, Balai Pustaka, Jakarta.

Dept. Agama RI, 1989, Al-Qur'an dan Terjemahnya, Jakarta.

Dini Aditya Rini, 2001, Prana Rahasia Penyembuhan Cara Yoga, PT Grasindo, Jakarta.

Djamaludin Ancok, 1994, Psikologi Islam, Solusi Islam Atas Problem-Problem Psikologi, Pustaka Pelajar, Yogyakarta.

Gerald Corey, 1997, Konseling dan Psikoterapi, Teori Dan Praktek, Eresco, Bandung.

Helen Graham, 1998, Penyembuhan Dengan Warna, Gramedia Pustaka Utama, Jakarta.

Irmansyah Efendi, 2001, Kundalini, Gramedia Pustaka Utama, Jakarta.

Jalaluddin Rakhmat, 2001, Perwujudan Amal, Buletin Dakwah Masjid AlMunawaroh, No 180, Edisi 28 Januari 2001, 
Yayasan Muthahari, Bandung.

Joe H Slate, 2002, Energi Aura, Gramedia

Pustaka Utama, Jakarta.

Johana E Prawita Sari, 2002, Psikoterapi,

Pendekatan Konfensional dan Kontenporer, Pustaka Pelajar, Yogyakarta.

Kompas, 2001, Energi Reiki, Prana dan

Cikung Yang Menyedot Peminat, Jakarta

Kuntowijoyo, 1993, Paradigma Islam, Interpretasi Untuk Aksi, Mizan, Bandung.

Linda O Riordan, 2002, Seni Penyembuhan Sufi, Serambi, Jakarta.

Larry. M.D Dossey, 1997, Healing Word, Gramedia Pustaka Utama, Jakarta.

Muhammad Hamdani Bakran Adz-Dzaky, 2001, Psikoterapi dan Konseling Islam, Fajar Pustaka Baru, Yogyakarta.

Muhammad H Anshori Sidik, 1995, Pengembangan Wawasan IPTEK Pondok Pesantren, PT Bumi Aksara, Jakarta.

My ron Weiner, 1977,Modernisasi Dinamika Pertumbuhan, Gadjah Mada University Press, Yogyakarta.

Nurkholis Majid, 1998, Islam Kemodernan dan Ke-Indonesiaan, Mizan, Bandung 